\title{
Antinociceptive, Antipyretic and Antimicrobial Activities of Chrozophora tinctoria Extracts
}

\author{
A. A. SHER, J. BAKHT ${ }^{1 *}$ AND K. KHAN ${ }^{2}$ \\ Hazara University Mansehra, ${ }^{1}$ Institute of Biotechnology and Genetic Engineering, The University of Agriculture Peshawar, \\ ${ }^{2}$ Veterinary Research Institute Peshawar, KPK Pakistan
}

\section{Sher et al.: Pharmaceutical Evaluation of Chrozophor atinctoria}

\begin{abstract}
The antinociceptive, antipyretic and antimicrobial activities possessed by different solvent extracts of Chrozophora tinctoria were investigated. Analgesic activity of the crude methanol extract was studied using the hot plate and acetic acid-induced writhing methods and antipyretic activity using standard procedures on mice. Chrozophora tinctoria extract had highest latency time on the hot plate. The plant extracts reduced the number of abdominal constriction by $50 \%$ at a dose of $150 \mathrm{mg} / \mathrm{kg}$. The antipyretic effect of all doses tested was comparable to that of normal saline. Maximum decrease in the body temperature of the mice was observed at a dose of $300 \mathrm{mg} / \mathrm{kg}$ extract. Ethyl acetate extract revealed good antibacterial potential against Salmonella typhi (83 \% inhibition) and Shigella sonnei (63\% inhibition). Chloroform extract showed highest antifungal activity against Rhizopus sp. (68\% inhibition).
\end{abstract}

Key words: Antibacterial, antifungal, antipyretic, Chrozophora tinctoria

People around the world appear to prefer herbal medicine over allopathy due to higher incidence of side effects. Herbal medicines could be regarded as safe to both the human health and the environment besides having both the aromatic and flavouring qualities. Herbs are being utilized for different remedial activities since ancient times. Initially medicinal plants were used in pure natural form (as teas, cataplasm, pulverized and other plant products $)^{[1,2]}$. The use of specific herbs for the treatment of different health issues were passed down from generation to generation in history. Medicinal herbs used for the contents of cocaine, codeine, digitoxin, and quinine, are still in use for various health needs ${ }^{[3,4]}$. Medicinal plants contained active constituents that can be used as antimicrobial agents ${ }^{[5-8,9]}$. The isolation, separation and classification of biologically active compounds from medicinal herbs is a continuing research.

Chrozophora tinctoria belongs to the family Euphorbiaceae, sub-family Acalyphoideae, tribe chrozophoreae and sub-tribe chrozophorinae. Chrozophora tinctoria, an annual plant is also known as, dyer's cróton, giradol or turnsole ${ }^{[10]}$. This plant is commonly found in different countries of the world including Africa, tropical Asia including India, Pakistan and Europe. C. tinctoria contained flavonoids, alkaloids,

${ }^{*}$ Address for correspondence E-mail: jehanbakht@yahoo.co.uk coumarins and phenylpropanoid glycosides ${ }^{[11,12]}$. C. tinctoria can be used for the treatment of different health issues including wound healing in diabetics ${ }^{[13]}$.

\section{MATERIALS AND MEHTODS}

Plants of $C$. tinctoria were collected from the mountains of Mohmand Agency, Khyber Pakhtunkhwa (KPK) Pakistan. The plant specimen was identified in the Department of Botany, Islamia College, Peshawar, Pakistan. The research project was approved by the Institutional Ethics Committee. All guidelines and Principles of Laboratory Animal Care (NIH publication No. 85-23, revised in 1985) were followed during the course of the experiment.

\section{Crude extract preparation:}

The plant materials were cut after washing with water, shade-dried and ground in an electric grinder. One kilogram of the powdered plant material was soaked in 51 of methanol at $25^{\circ}$ in the dark for $7 \mathrm{w}$, shaked

This is an open access article distributed under the terms of the Creative Commons Attribution-NonCommercial-ShareAlike 3.0 License, which allows others to remix, tweak, and build upon the work non-commercially, as long as the author is credited and the new creations are licensed under the identical terms 
thrice a day and filtered through a Whatman filter paper No.1. The solid remains was mixed with 2.51 of fresh methanol and the whole process was repeated three times. All the filtered methanol extracts were mixed and evaporated under vacuum pressure at $45^{\circ}$. The crude extract was divided into two parts, one was used as the crude extract and the second was fractionated with different solvents.

\section{Analgesic activity:}

Albino mice of either sex (18-22 g) were used in the present investigation. The analgesic activity of the plant extract was determined using the hot-plate method $^{[14]}$. Thirty mice were randomly allotted to 5 treatment groups comprises of 6 mice each. First group was given the standard drug morphine, second received $0.9 \%$ saline (control) and the remaining 3 groups were treated with plant extract at concentrations of 50,100 and $150 \mathrm{mg} / \mathrm{kg}$. All drugs were given orally as a suspension and normal saline and the standard drug was administered intraperitoneally (IP). An interval of 30 min was given to ensure proper absorption of the administered substances. The animals, which showed fore paw licking or jumping response within 6-8 $\mathrm{s}$ were selected for further investigation. The mice were put on the hot plate $\left(55 \pm 0.5^{\circ}\right)$ and the reaction time to thermal pain was noted. A cut off time $(+10 \mathrm{~s})$ was allowed to avoid thermal injury to the paws. The reaction time was recorded both before and 30,60, 90, 120 and $180 \mathrm{~min}$ after the administration of the test or standard drugs.

The mean reaction time for each treated group was determined and percent increase in reaction time (\% I) was derived using the Eqn., \% I = ((It-Io)/ Io) $\times 100$, where, It was the reaction time at time $t$, and Io was the reaction time at time zero $(0 \mathrm{~h})$. The mice were subjected to the same test procedure at +30 , $+60,+120$, and +180 min after the administration of test/standard/control drug ${ }^{[15]}$. Mice were sacrificed by cervical dislocation at the end of the experiment.

Mice of either sex weighing 18-22 $\mathrm{g}$ were used to measure analgesic activity using the acetic acid (AA)induced writhing test. Mice were withdrawn from food and water $2 \mathrm{~h}$ before the start of the experiment. Mice were divided into 5 groups, each group consisting of 6 animals. First group served as the negative control (normal saline $\mathrm{ml} / \mathrm{kg}$ ), second group as positive control (aspirin $50 \mathrm{mg} / \mathrm{kg}$ ), while third, fourth and fifth group received the plant extract orally in concentration of $50,100,150 \mathrm{mg} / \mathrm{kg}$. Writhing behaviour was observed in mice after administering $1 \%$ AA, IP. Number of abdominal constrictions occurring over the period of 20 min was counted after 5 min of administration of $1 \%$ AA $(10 \mathrm{ml} / \mathrm{kg})^{[16]}$. The plant extract $(50,100$, $150 \mathrm{mg} / \mathrm{kg}$ ), aspirin or $0.9 \%$ sodium chloride was administered IP $30 \mathrm{~min}$ before $1 \%$ AA administration. Percent analgesia was calculated using the Eqn., \% protection $=100$ - (number of writhes in experimental group $\times 100$ /number of writhes in control).

Antipyretic activity of the crude extract of C. tinctoria was determined following the method of Adams et al. ${ }^{[17]}$. Normal body temperature of each mouse was noted and pyrexia was induced in mice by injecting $20 \%$ aqueous suspension of Brewer's yeast $(10 \mathrm{ml} / \mathrm{kg})$ subcutaneously. All groups were withdrawn from food overnight. However, accesses to drinking water was allowed and rectal temperature of each mouse was noted after $24 \mathrm{~h}$. Rise in temperature more than $0.7^{\circ} \mathrm{F}$ was regarded as induction of pyrexia. For different treatments, the mice were divided into 5 groups, 6 mice each. Group I was treated with saline $(10 \mathrm{ml} / \mathrm{kg})$ as a negative control, group II received paracetamol $(150 \mathrm{mg} / \mathrm{kg})$ as the standard drug while the remaining groups (III, IV and V) were treated orally with plant extracts in 100, 200 and $300 \mathrm{mg} / \mathrm{kg}$ concentrations, respectively. Rectal temperature was again noted at $0.5,1,2,3$ and $4 \mathrm{~h}$ after treatment.

\section{Antimicrobial activity:}

Antibacterial activity of different fractions was determined by disc diffusion methods as reported in Khajuria et al. ${ }^{[18]}$ and antifungal activity by Ramdas et al. ${ }^{[19]}$. Plates containing nutrient agar media were inoculated with $1 \mathrm{~d}$ cultures of microbial inoculums. Three Whatman No. 1 filter paper discs (6 mm diameter) were placed on the media in Petri plates. Test plant samples in 1 and $2 \mathrm{mg} /$ disc concentration (6 and $12 \mu \mathrm{l}$ volumes) were applied on to the discs. Standard drugs (ciprofloxacin and clotrimazole at dose of $50 \mu \mathrm{g}$ per $12 \mu \mathrm{l}$ ) as the positive control and DMSO (12 $\mu \mathrm{l} /$ disc) as the negative control were also applied on the discs. Inoculated plates were kept at $37^{\circ}$ for 18-24 $\mathrm{h}$ and zones of inhibition were recorded in millimetre in each plate.

\section{Statistical analysis:}

Data was expressed as mean of triplicate determinations. For statistical analysis, MSTATC computer software was used ${ }^{[20]}$. Standard error of the means and level of significance $(p<0.05)$ were calculated for each treatment. 


\section{RESULTS AND DISSCUSSION}

The crude methanol extract of $C$. tinctoria was screened for analgesic activity using the hot plate method in doses of 50, 100 and $150 \mathrm{mg} / \mathrm{kg}$ (Table 1). The data showed that the mean pain latency time of the $50 \mathrm{mg} / \mathrm{kg}$ extract-treated group was $13 \pm 0.89$ at $0 \mathrm{~min}$. After administering the extract, the latency time was found to be increased to $14.83 \pm 2.136$ and $14 \pm 2.097 \mathrm{~s}$ at 30 and 60 min compared to initial latency time of the same group or the normal saline group. The data also indicated that similar rise in latency was observed after 90 and $120 \mathrm{~min}(9.43 \pm 1.47 \mathrm{~s})$. However, latency time increased to $12.33 \pm 2.065 \mathrm{~s}$ after $180 \mathrm{~min}$. Similarly, the latency time of the plant extract in $100 \mathrm{mg} / \mathrm{kg}$ dose group was noted as $11.83 \pm 1.47 \mathrm{~s}$ at $0 \mathrm{~min}$. Rise in reaction time was observed after 30,60 and $90 \mathrm{~min}$ measuring $12.66 \pm 0.816,13.66 \pm 1.21,16.33 \pm 0.516 \mathrm{~s}$ compared with initial reaction time and latency time of saline group. The extract of $150 \mathrm{mg} / \mathrm{kg}$ showed significant $(\mathrm{p}<0.05)$ effects after 60,90 and $120 \mathrm{~min}$ showing increase in latency time of $15.66 \pm 2.065$, $17 \pm 1.26$ and $15 \pm 2.96 \mathrm{~s}$ compared to the initial time noted at $0 \mathrm{~min}$ and saline group. Morphine-treated groups significantly $(\mathrm{p}<0.05)$ increased pain latency induced by the hot plate. Significant $(\mathrm{p}<0.05)$ effects were also shown by $100 \mathrm{mg} / \mathrm{kg}$ plant extract after 60, 90 and 120 min compared to morphine-treated group. Similar results were also noted for $150 \mathrm{mg} / \mathrm{kg}$ concentration after 60, 90 and $120 \mathrm{~min}$.

The data indicated that the mean number of writhes in control group was $75.83 \pm 3.65$ when tested AA-induced method (Table 2). Aspirin at the dose of $100 \mathrm{mg} / \mathrm{kg}$ showed $74.08 \%$ inhibition of abdominal constriction resulting in the mean number of $19.66 \pm 2.160$ writhings. The crude methanol extract at $50 \mathrm{mg} / \mathrm{kg}$ dose resulted in $18.47 \%$ inhibition of abdominal constriction and showed lower mean number of writhes i.e. $61.83 \pm 2.31$. Similarly, $100 \mathrm{mg} / \mathrm{kg}$ concentration inhibited the abdominal constriction up to $26.16 \%$ resulting in the mean numbers of $56 \pm 4.049$ writhes. The crude extracts at $150 \mathrm{mg}$ significantly $(\mathrm{p}<0.05)$ reduced the number of abdominal constrictions to $38 \pm 4.85$ resulting in $49.89 \%$ inhibition of writhes.

The antipyretic activity of $C$. tinctoria crude extract was evaluated at different concentrations in mice (Table 3). The mean temperature of control group prior to Brewer's yeast injection was $99.03 \pm 0.33^{\circ} \mathrm{F}$ and the average temperature increased to $102.01 \pm 0.36^{\circ} \mathrm{F}$ after Brewer's yeast injection. After 30 min, a gradual rise in the body temperature of the control group was noted $\left(102.28 \pm 0.21^{\circ} \mathrm{F}\right)$. Similarly, a slight fall in body temperature was observed measuring $101.95 \pm 0.30^{\circ} \mathrm{F}$, $101.65 \pm 0.30^{\circ} \mathrm{F}, 101.4 \pm 0.32^{\circ} \mathrm{F}$, and $101.03 \pm 0.186^{\circ} \mathrm{F}$ after $1,2,3$ and $4 \mathrm{~h}$, respectively. The average temperature of paracetamol group before Brewer's yeast injection was $98.91 \pm 0.24^{\circ} \mathrm{F}$, which raised to $102.43 \pm 0.41^{\circ} \mathrm{F}$ after brewer's yeast. After injection of paracetamol, a continued fall in the rectal temperature of mice was recorded in a time-dependant manner. The rectal average temperature of paracetamol group was $102.11 \pm 0.42^{\circ} \mathrm{F}, 101.95 \pm 0.30^{\circ} \mathrm{F}, 100.3 \pm 0.39^{\circ} \mathrm{F}$, $100.2 \pm 0.54^{\circ} \mathrm{F}$ and $99.41 \pm 0.37^{\circ} \mathrm{F}$, at $0.5,1,2,3$ and $4 \mathrm{~h}$, respectively.

TABLE 1: EFFECT OF CRUDE METHANOL EXTRACT OF CHROZOPHORA TINCTORIA ON THERMALLY INDUCED PAIN IN MICE

\begin{tabular}{|c|c|c|c|c|c|c|c|}
\hline \multirow{2}{*}{ Group } & \multirow{2}{*}{$\begin{array}{c}\text { Dose } \\
\mathrm{mg} / \mathrm{kg}\end{array}$} & \multicolumn{6}{|c|}{ Mean pain latency (seconds) } \\
\hline & & $0 \mathrm{~min}$ & After $30 \mathrm{~min}$ & After $60 \mathrm{~min}$ & After $90 \mathrm{~min}$ & After $120 \mathrm{~min}$ & After $180 \mathrm{~min}$ \\
\hline Saline & $-\cdots$ & $10.83 \pm 1.32$ & $11.33 \pm 0.81$ & $11.66 \pm 0.81$ & $11.66 \pm 1.63$ & $10.33 \pm 2.160$ & $11.83 \pm 1.169$ \\
\hline Morphine & 5 & $12.16 \pm 1.72$ & $16.5 \pm 1.87$ & $18.16 \pm 1.60$ & $19.33 \pm 1.36$ & $11.5 \pm 1.37$ & $11.83 \pm 1.72$ \\
\hline Chrozophora & 50 & $13 \pm 0.89$ & $14.83 \pm 2.136$ & $14 \pm 2.097$ & $9.83 \pm 1.47$ & $9.83 \pm 1.47$ & $12.33 \pm 2.065$ \\
\hline tinctoria & 100 & $11.83 \pm 1.47$ & $12.66 \pm 0.816$ & $13.66 \pm 1.21$ & $16.33 \pm 0.516$ & $13.33 \pm 1.032$ & $13.33 \pm 1.21$ \\
\hline extract & 150 & $11.83 \pm 1.47$ & $13.16 \pm 2.31$ & $15.66 \pm 2.065$ & $17 \pm 1.26$ & $15 \pm 2.96$ & $12.66 \pm 2.065$ \\
\hline
\end{tabular}

Crude methanol extract of $C$. tinctoria was tested at 50,100 and $150 \mathrm{mg} / \mathrm{kg}$ doses. Values are expressed as mean \pm SEM

TABLE 2: EFFECT OF CRUDE METHANOL EXTRACT OF CHROZOPHORA TINCTORIA ON ACETIC ACIDINDUCED WRITHING IN MICE

\begin{tabular}{lcccc}
\hline Groups & Treatments & dose $(\mathrm{mg} / \mathrm{kg})$ & Number of writhes mean \pm SEM & Inhibition (\%) \\
\hline Control & Normal saline & --- & $75.83 \pm 3.65$ & \\
Standard & Aspirin & $50 \mathrm{mg}$ & $19.66 \pm 2.160$ & 74.08 \\
& $-\cdots$ & $50 \mathrm{mg}$ & $61.83 \pm 2.31$ & 18.47 \\
Crude methanol extract & --- & $100 \mathrm{mg}$ & $56 \pm 4.049$ & 26.16 \\
& $-\cdots$ & $150 \mathrm{mg}$ & $38 \pm 4.85$ & 49.89 \\
\hline
\end{tabular}

Crude methanol extract of $C$. tinctoria was tested at 50, 100 and $150 \mathrm{mg} / \mathrm{kg}$ doses. Values are expressed as mean $\pm \mathrm{SEM}$ 
www.ijpsonline.com

TABLE 3: ANTIPYRETIC ACTIVITY OF CRUDE METHANOL EXTRACT OF CHROZOPHORA TINCTORIA

\begin{tabular}{|c|c|c|c|c|c|c|c|c|}
\hline \multirow[b]{2}{*}{ Treatment } & \multirow{2}{*}{$\begin{array}{l}\text { Dose } \\
\mathrm{mg} / \mathrm{kg}\end{array}$} & \multirow{2}{*}{$\begin{array}{c}\text { Average } \\
\text { temperature } \\
\left({ }^{\circ} \mathrm{F}\right) \text { before } \\
\text { Brewer's } \\
\text { yeast } \\
\text { injection }\end{array}$} & \multirow{2}{*}{$\begin{array}{c}\text { Average } \\
\text { temperature } \\
\left({ }^{\circ} \mathrm{F}\right) \text { after } \\
\text { Brewer's } \\
\text { yeast } \\
\text { injection }\end{array}$} & \multicolumn{5}{|c|}{$\begin{array}{c}\text { Average temperature }\left({ }^{\circ} \mathrm{F}\right) \text { after Brewer's yeast injection at } \\
\text { different time intervals }\end{array}$} \\
\hline & & & & After $0.5 \mathrm{~h}$ & After $1 \mathrm{~h}$ & After $2 \mathrm{~h}$ & After $3 \mathrm{~h}$ & $4 \mathrm{~h}$ \\
\hline Control/saline & & $99.03 \pm 0.33$ & $102.01 \pm 0.36$ & 102.2 & 101. & 101 & .32 & \\
\hline Paracetamol & 5 & 98.91 & $102.43 \pm 0.41$ & $102.11 \pm 0.42$ & $100.78 \pm 0.63$ & 100.3 & 0.54 & .37 \\
\hline ud & 100 & $99.11 \pm 0.147$ & $101.91 \pm 0.47$ & $101.78 \pm 0.40$ & $101.78 \pm 0.40$ & $101.4 \pm 0.37$ & $100.55 \pm 0.39$ & $100.2 \pm 0.309$ \\
\hline 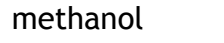 & 200 & $98.61 \pm 0.37$ & $101.98 \pm 0.49$ & $101.35 \pm 0.472$ & $100.78 \pm 0.44$ & $100.51 \pm 0.594$ & $100.05 \pm 0.50$ & $100.05 \pm 0.686$ \\
\hline & 300 & $99 \pm 0.282$ & $101.85 \pm 0.266$ & $101.15 \pm 0.27$ & $100.1 \pm 0.45$ & $99.51 \pm 0.306$ & $99.51 \pm 0.26$ & $99.25 \pm 0.20$ \\
\hline
\end{tabular}

Crude methanol extract of $C$. tinctoria was tested at 50,100 and $150 \mathrm{mg} / \mathrm{kg}$ doses. Values are expressed as mean $\pm \mathrm{SEM}$

Similarly, the rectal temperature was also recorded in groups that received crude extract doses of 100,200 and $300 \mathrm{mg}$ at different time intervals. At $100 \mathrm{mg}$ dose the average temperature before Brewer's yeast injection was $99.11 \pm 0.147^{\circ} \mathrm{F}$, which increased to $101.91 \pm 0.47^{\circ} \mathrm{F}$ after the treatment. The rectal temperature of the mice was $101.78 \pm 0.40^{\circ} \mathrm{F}, 101.78 \pm 0.40^{\circ} \mathrm{F}, 101.4 \pm 0.37^{\circ} \mathrm{F}$, $100.55 \pm 0.39^{\circ} \mathrm{F}$ and $100.2 \pm 0.309^{\circ} \mathrm{F}$ after $100 \mathrm{mg}$ dose after $0.5,1,2,3$ and $4 \mathrm{~h}$, respectively. However, it showed a decrease in temperature from $101.91 \pm 0.47^{\circ} \mathrm{F}$ to $100.55 \pm 0.39^{\circ} \mathrm{F}$ after $3 \mathrm{~h}$. The average temperature before Brewer's yeast injection was $98.61 \pm 0.37^{\circ} \mathrm{F}$, which raised to $101.98 \pm 0.49^{\circ} \mathrm{F}$ by administering $200 \mathrm{mg}$ dose. Similarly, the rectal temperature was $101.35 \pm 0.472^{\circ} \mathrm{F}, 100.78 \pm 0.44^{\circ} \mathrm{F}, 100.51 \pm 0.594^{\circ} \mathrm{F}$, $100.05 \pm 0.50^{\circ} \mathrm{F}$ and $100.05 \pm 0.686^{\circ} \mathrm{F}$, respectively in $200 \mathrm{mg}$ dose after $0.5,1,2,3$ and $4 \mathrm{~h}$. The average temperature before Brewer's yeast injection was $99 \pm 0.282^{\circ} \mathrm{F}$ in $300 \mathrm{mg}$ dose and after Brewer's yeast induction the temperature became $101.85 \pm 0.266^{\circ} \mathrm{F}$. A decrease in temperature was noticed after $0.5,1,23$ and $4 \mathrm{~h}\left(101.15 \pm 0.27^{\circ} \mathrm{F}, 100.1 \pm 0.45^{\circ} \mathrm{F}, 99.51 \pm 0.306^{\circ} \mathrm{F}\right.$, $99.51 \pm 0.26^{\circ} \mathrm{F}$ and $99.25 \pm 0.20^{\circ} \mathrm{F}$, respectively). A significant $(\mathrm{p}<0.05)$ antipyretic effect was noted in $300 \mathrm{mg}$ dose. It showed $1.64^{\circ} \mathrm{F}$ fall in temperature after $2 \mathrm{~h}$ and came close to the normal body temperature of mice after $4 \mathrm{~h}$.

Crude methanol extract, petroleum ether, chloroform, ethyl acetate, n-butanol and aqueous extracts of C. tinctoria were tested against Escherichia coli for possible antibacterial activity (fig. 1A). Almost all the extracts showed activity (zone of inhibition) against $E$. coli at concentrations of 1 and $2 \mathrm{mg} /$ disc except the aqueous extract. Crude methanol extract showed $23.33 \pm 0.50 \%$ zone of inhibition in concentration of $1 \mathrm{mg} / \mathrm{disc}$ and $33.33 \pm 0.70 \%$ in $2 \mathrm{mg} / \mathrm{disc}$. Chloroform extract produced $20.00 \pm 0.35$ and $46.70 \pm 0.56 \%$ inhibition zones at 1 and $2 \mathrm{mg} /$ disc, respectively.
Similarly, the zone of inhibition for ethyl acetate extract was $30.00 \pm 0.62 \%$ in $1 \mathrm{mg} /$ disc and $40.00 \pm 0.56 \%$ in $2 \mathrm{mg} / \mathrm{disc}$. These results also revealed that most of the extracts showed activity against Salmonella typhi at both concentrations except with chloroform and aqueous extracts (fig. 1B). Crude methanol extracts showed $23.33 \pm 0.62 \%$ zone of inhibition in $1 \mathrm{mg} /$ disc and $56.70 \pm 0.30$ in $2 \mathrm{mg} /$ disc concentration. Ethyl acetate extract showed $63.33 \pm 0.30 \%$ zone of inhibition in $1 \mathrm{mg} /$ disc and $83.33 \pm 0.20 \%$ zone of inhibition in $2 \mathrm{mg} /$ disc compared to controls.

Crude methanol, n-butanol and ethyl acetate extracts revealed activity against Pseudomonas aeruginosa at the tested concentrations (fig. 1C). However, petroleum ether, chloroform and aqueous extracted samples did not show any activity at both concentrations. Crude methanolic extracts measured $23.33 \pm 0.20 \%$ zone of inhibition in $1 \mathrm{mg} /$ disc and $26.70 \pm 0.50 \%$ in $2 \mathrm{mg} /$ disc concentrations. Ethyl acetate extracted samples revealed $26.70 \pm 0.20$ and $30.00 \pm 0.20 \%$ zones of inhibition in 1 and $2 \mathrm{mg} /$ disc, respectively. All extracts obtained from $C$. tinctoria showed activity against Providencia sp. at both concentrations (fig. 1D). Crude methanolic extract measured $43.33 \pm 0.40 \%$ zone of inhibition in $1 \mathrm{mg} /$ disc and $53.33 \pm 0.62 \%$ in $2 \mathrm{mg} /$ disc concentrations against Providencia sp. Petroleum ether extracts showed $36.70 \pm 0.50$ and $43.33 \pm 0.50 \%$ zones of inhibition at 1 and $2 \mathrm{mg} /$ disc, respectively.

Crude methanol, petroleum ether, chloroform, ethyl acetate, n-butanol and aqueous extracts demonstrated different zones of inhibition against Proteus mirabilis in 1 and $2 \mathrm{mg} /$ disc concentration except chloroform and aqueous extracts (fig. 1E). Crude methanol extract gave $20.00 \pm 0.50$ and $23.33 \pm 0.80 \%$ zones of inhibition in 1 and $2 \mathrm{mg} /$ disc, respectively. Similarly, ethyl acetate extract showed $16.70 \pm 0.50$ and $23.33 \pm$ $0.50 \%$ zones of inhibition in 1 and $2 \mathrm{mg} / \mathrm{disc}$. $\mathrm{n}$-Butanol extract showed activity of $13.33 \pm 0.20$ and $40.00 \pm$ 
$0.40 \%$ in 1 and $2 \mathrm{mg} /$ disc concentrations against the same microbe. The data also revealed that crude methanol, petroleum ether and ethyl acetate extracts reduced the growth of Shigella sonnei but not chloroform, n-butanol and aqueous extracts (fig. 1F). Highest antibacterial activities were shown by crude methanol and ethyl acetate extracts compared to control. Crude methanol extract yielded $20 \pm 0.20$ and $40 \pm$ $0.62 \%$ zones of inhibition in 1 and $2 \mathrm{mg} / \mathrm{disc}$ concentrations, respectively. Similarly, ethyl acetate extract exhibited antibacterial activity of $53.33 \pm 0.10$

A.

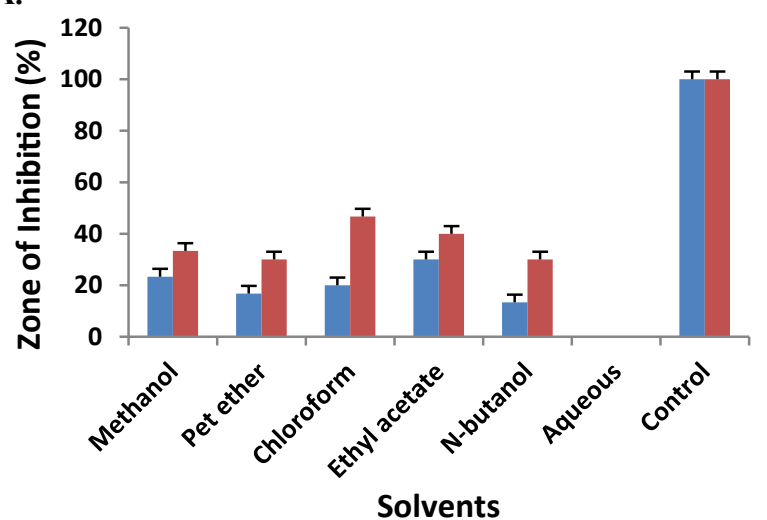

C.

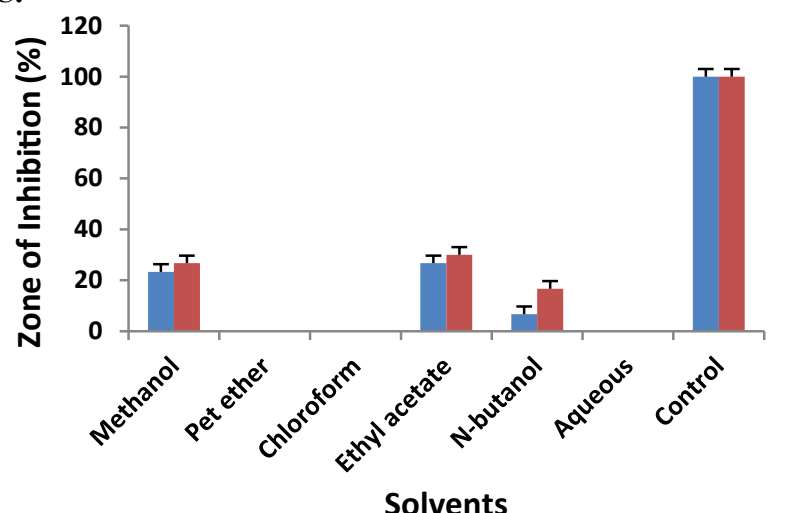

E.

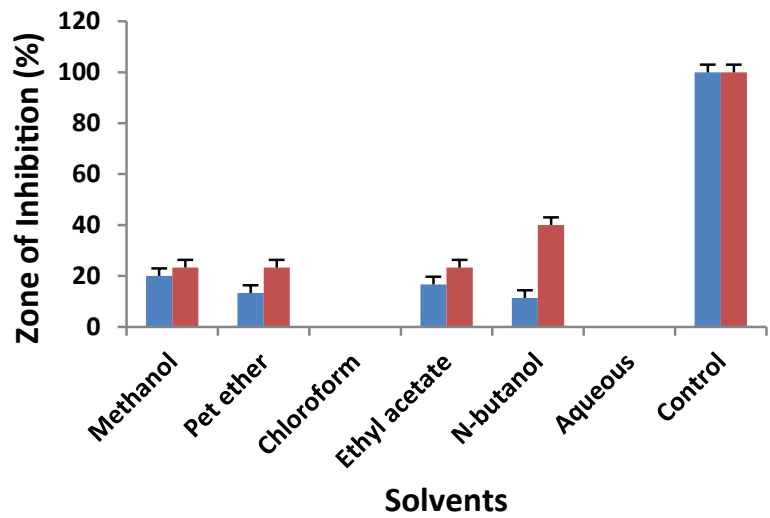

and $63.33 \pm 0.26 \%$ in 1 and $2 \mathrm{mg} /$ disc, respectively against $S$. sonnei. Petroleum ether, n-butanol and aqueous extracted samples showed no activity against Citrobacter sp. (fig. 2A). Crude methanol extract reduced the growth of the same bacterium by $23.33 \pm 0.50$ and $33.33 \pm 0.43 \%$ in 1 and $2 \mathrm{mg} /$ disc concentrations, respectively. Ethyl acetate extract showed activity of $33.33 \pm 0.40$ and $36.70 \pm 0.40 \%$ at concentrations of 1 and $2 \mathrm{mg} /$ disc, respectively against Citrobacter sp.

Crude methanol, petroleum ether, chloroform, ethyl acetate, n-butanol and aqueous extracts were also tested

B.

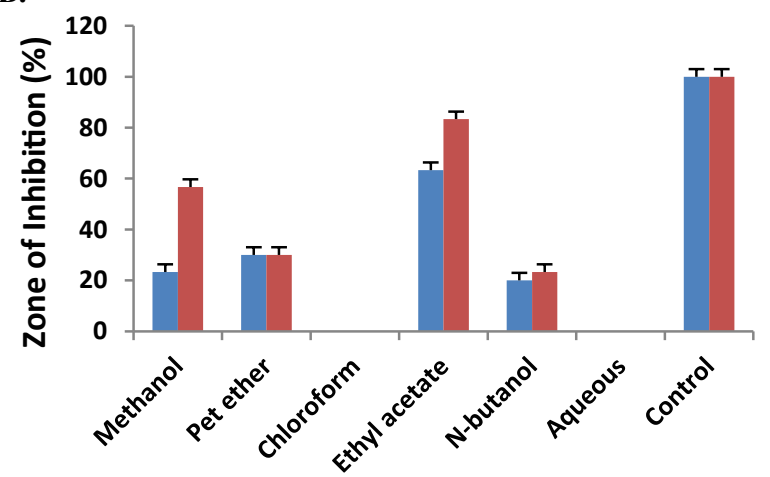

Solvents

D.

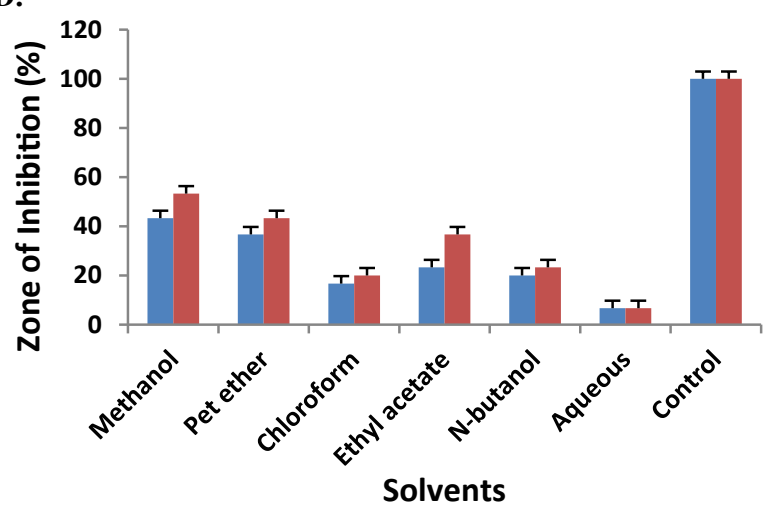

F.

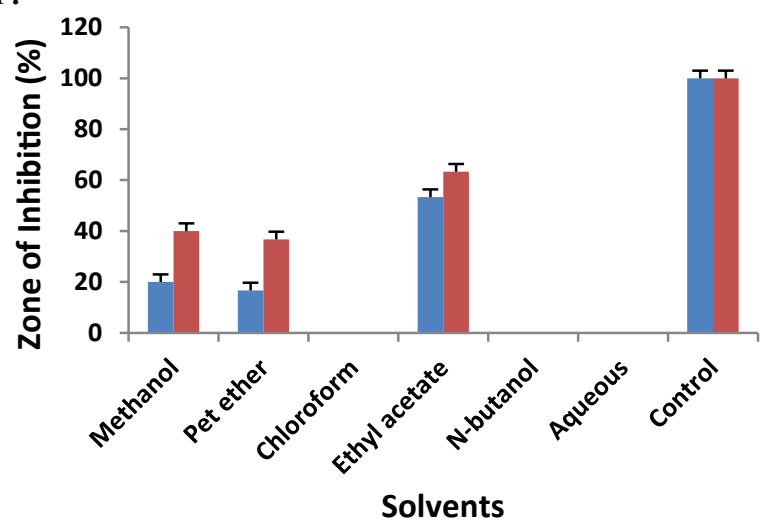

Fig. 1: Antibacterial activity of different extracts of Chrozophora tinctoria

Antibacterial activity of different extracts of Chrozophora tinctoria against (A) Escherichia coli, (B) Salmonella typhi, (C) Pseudomonas aeruginosa, (D) Providencia sp., (E) Proteus mirabilis and (F) Shigella sonnei, using disc diffusion assay. Bar shows LSD value at $\mathbf{p}<0.05$. $1 \mathrm{mg} / \mathrm{disc} ; \quad 2 \mathrm{mg} / \mathrm{disc}$ 
A.

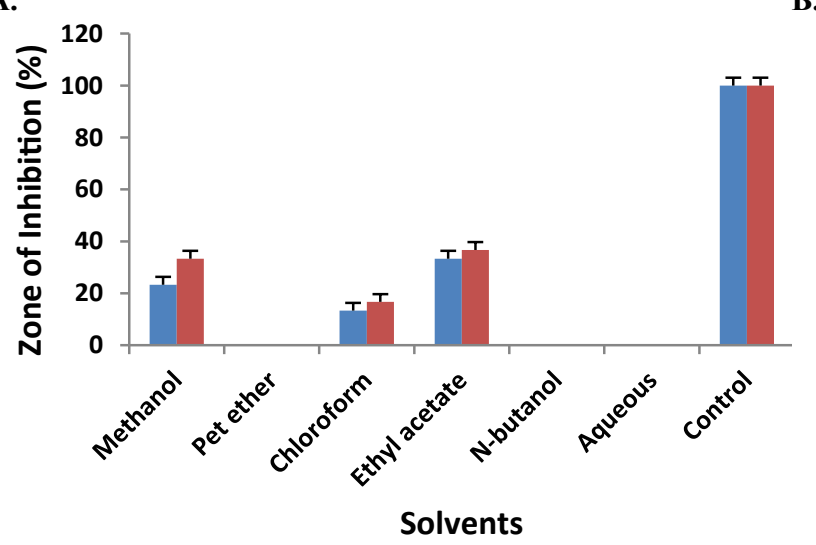

B.

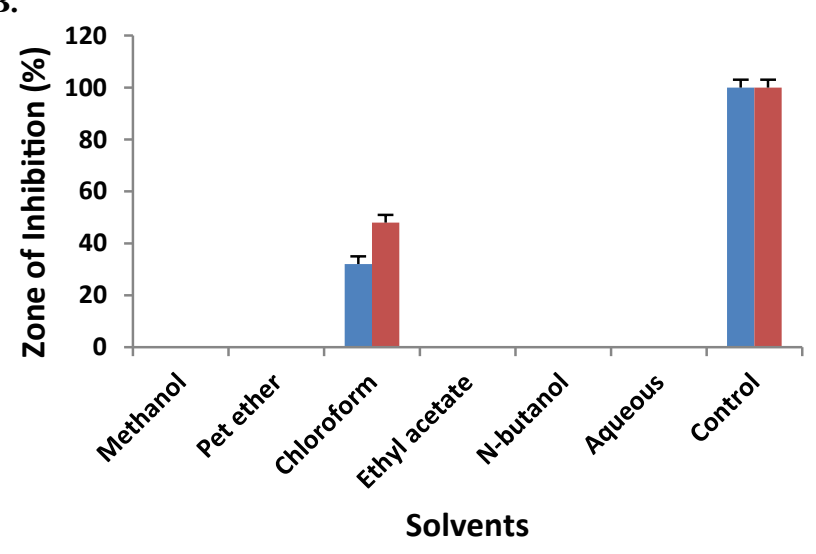

C.

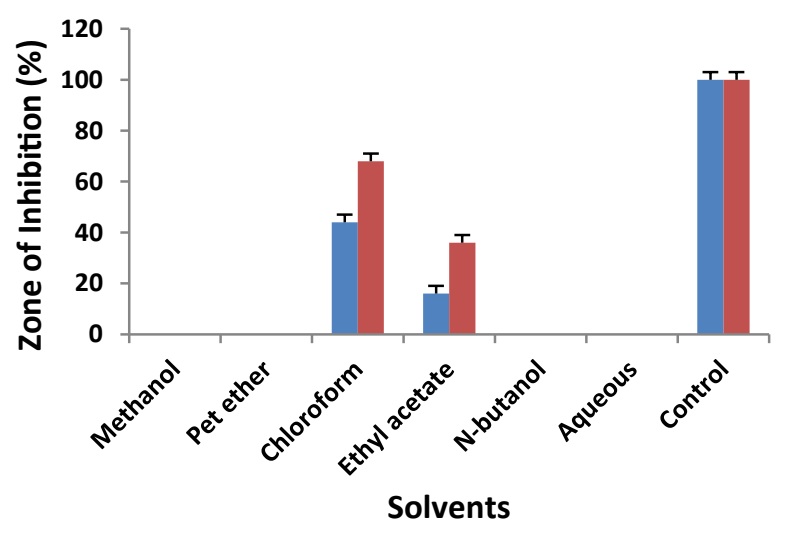

Fig. 2: Antibacterial activity of different extracts of Chrozophora tinctoria

Antibacterial activity of different extracts of Chrozophora tinctoria against (A) Citrobacter sp., (B) Aspergillus fumigates and (C) Rhizopus sp. using disc diffusion assay. Bar shows LSD value at $\mathrm{p}<0.05$. $\square 1 \mathrm{mg} / \mathrm{disc} ; \approx 2 \mathrm{mg} / \mathrm{disc}$

against Aspergillus fumigatus as shown in fig. $2 \mathrm{~B}$. Almost all the extracts showed no activity against $A$. fumigatus at both concentrations except for chloroform extract, which showed $32 \pm 0.34 \%$ inhibitory activity at $1 \mathrm{mg} /$ disc and $48 \pm 0.20 \%$ inhibitory activity at $2 \mathrm{mg} /$ disc. All the extracts of $C$. tinctoria did not reduce the activity of Penicillium chrysogenum at both concentrations showing no antifungal activity. Most of the extracts showed no zones of inhibition against Rhizopus sp. except chloroform and ethyl acetate extracts (fig. 2C). Chloroform extract inhibited bacterial growth by $44 \pm 0.17$ and $68 \pm 0.45 \%$ at 1 and $2 \mathrm{mg} /$ disc concentrations, respectively. Similarly, ethyl acetate extract produced $16 \pm 0.17$ and $36 \pm 0.30 \%$ inhibition at 1 and $2 \mathrm{mg} / \mathrm{disc}$, respectively (fig. 2C).

Hot plate method is more sensitive to centrally acting analgesics. Thermal-induced nociception indicates narcotic involvement ${ }^{[21]}$. The methanol extract of C. tinctoria significantly $(\mathrm{p}<0.05)$ and dose-dependently protected the mice against thermally induced pain stimulus. However, the extract at $150 \mathrm{mg} / \mathrm{kg}$ showed increased latency time. Magaji et al. ${ }^{[22]}$ reported comparatively similar results in Securinega virosa (Euphorbiaceae) where the methanol extract of the root bark at $12.5 \mathrm{mg} / \mathrm{kg}$ concentration showed significant $(\mathrm{p}<0.05)$ mean latency period of $14.20 \pm$ $1.61 \mathrm{~s}$ and at higher concentration of $25 \mathrm{mg} / \mathrm{kg}$ the mean reaction time increased to $17.60 \pm 1.08 \mathrm{~s}$. AAinduced method was used for identifying peripheral analgesia. Crude methanol extract significantly $(\mathrm{p}<0.05)$ affected the AA-induced abdominal writhes in mice. Crude methanol extract resulted in the highest inhibition of abdominal constriction when given at $150 \mathrm{mg} / \mathrm{kg}$. Crude methanol extracts inhibited $50 \%$ of the abdominal constriction and proved to be $50 \%$ antinociceptive at $150 \mathrm{mg} / \mathrm{kg}$. Jigam et al. ${ }^{[23]}$ reported that the extract of Curvularia senegalensis inhibited abdominal constriction.

Crude methanol extracts of $C$. tinctoria at $100 \mathrm{mg} / \mathrm{kg}$ showed significant $(\mathrm{p}<0.05)$ effects on antipyretic activity. A decline in temperature occurred up to $100.55 \pm 0.39^{\circ} \mathrm{F}$ and $100.2 \pm 0.309^{\circ} \mathrm{F}$, respectively as compared to control (normal saline) group after 3 and $4 \mathrm{~h}$. The extracts in $200 \mathrm{mg} / \mathrm{kg}$ dose revealed significant 
$(p<0.05)$ effects after 1, 2, 3 and $4 \mathrm{~h}$. A gradual fall in temperature occurred after $1 \mathrm{~h}$ and onward as compared with normal saline group. Similarly, extracts in $300 \mathrm{mg}$ dose also revealed significant $(\mathrm{p}<0.05)$ antipyretic activity. Increasing quantity of the extracts measured higher antipyretic activity. These results showed similarities to Euphorbia hirta belonging to family Euphorbiaceae where antipyretic activity was obtained at the sedative doses of 100 and $400 \mathrm{mg} / \mathrm{kg}$ on the yeast-induced hyperthermia ${ }^{[24]}$.

Most of the extracts of $C$. tinctoria were effective against the tested bacterial strains except aqueous extract where no activity at both concentrations was observed. Similar results are also reported by Igbinosa et al. ${ }^{[25]}$ who concluded that water extracts from the stem bark of Jatropha curcas (Euphorbiaceae) showed low antibacterial activity with inhibition zones ranging between 0 and $8 \mathrm{~mm}(0-26.67 \%)$ for different tested bacteria. Among different solvent extracted samples, crude methanol and ethyl acetate extracts showed activity above $50 \%$ against $S$. typhi and Providencia sp. and above $30 \%$ against E. coli, $S$. sonnei and Citrobacter sp. in highest concentration. Similarly, ethyl acetate extract was also effective against most human pathogens showing above $60 \%$ activity against $S$. typhi and $S$. sonnei in concentration of $2 \mathrm{mg} /$ disc and above $50 \%$ in concentration of $1 \mathrm{mg} /$ disc. Ethyl acetate extract reduced the growth of E. coli, Providencia sp. and Citrobacter sp. above $30 \%$. These results agree with Nelofar et al. ${ }^{[26]}$ who revealed that ethyl acetate extract was effective against Gram-positive and Gram-negative bacteria. Similarly, Usman et al. ${ }^{[27]}$ reported that ethyl acetate extract of C. senegalensis was effective to reduce the growth of Bacillus subtilis, E. coli, P. aeruginosa, Staphylococcus aureus, S. typhi and one fungus Aspergillus flavus. $C$. tinctoria extracts were also tested against A. fumigatus, P. chrysogenum and Rhizopus sp., but produced no activity against the microorganisms tested except the chloroform extract.

It could be concluded from these results that C. tinctoria extract possessed analgesic activity when given at a dose of $150 \mathrm{mg} / \mathrm{kg}$, inhibiting the abdominal constriction to $50 \%$. The antipyretic effect of crude methanol extract at a dose of $300 \mathrm{mg} / \mathrm{kg}$ revealed significant decrease in body temperature of mice. Different extracts were effective to reduce the growth of different strains of bacteria and fungi.

\section{Conflict of interest:}

The authors declare no conflict of interest.

\section{Financial support and sponsorship:}

Nil.

\section{REFERENCES}

1. Samuelsson G. Drugs of Natural Origin: a Textbook of Pharmacognosy. Stockholm; Swedish Pharmaceutical Press; 2004.

2. Balick MJ, Cox PA. Plants, People and Culture: The Science of Ethnobotany. New York: Scientific American Library; 1997.

3. Newman DJ, Cragg GM, Snader KM. The influence of natural products upon drug discovery. Nat Prod Rep 2000;17:215-34.

4. Kubmarawa D, Ajoku GA, Enweram NM, Okorie DA. Preliminary phytochemical and antimicrobial screening of 50 medicinal plants from Nigeria. Afr J Biotechnol 2007;64:1690-96.

5. Bakht J, Shehla K, Shafi M. In vitro antimicrobial activity of Allium cepa (dry bulbs) against Gram positive and Gram-negative bacteria and fungi. Pak J Pharm Sci 2014a;27:139-45.

6. Bakht J, Shaheen S, Shafi M. Antimicrobial potentials of Mentha longifolia by disc diffusion method. Pak J Pharm Sci 2014b; 27:939-45.

7. Bakht J, Gohar N, Shafi M. In vitro antibacterial and antifungal activity of different solvent extracted samples of Alhagi maurorum. Pak J Pharm Sci 2014;27:1955-61.

8. Ullah R, Bakht J, Shafi M. Antibacterial and anti-oxidant potential of Periploca hyaspidis. Bangladesh J Pharmacol 2015 10:645-51.

9. Osbourne AE. Performed antimicrobial compounds and plant defense against fungal attack. The Plant Cell 1966;8:1821-31.

10. http://www.ars-grin.gov/cgi-bin/npgs/html/taxon.pl?400209, 2006.

11. Mohamed KS. Phenylpropanoid glucosides from Chrozophora obliqua. Phytochemistry 2011;58:615-18.

12. Abdallah HM, Almowallad FM, Esmalt A, Shehata IA, AbdelSattar EA. Antiinflammatory activity of flavonoids from Chrozophora tinctoria. Phytochem Lett 2015;13:74-80.

13. Maurya H, Semwal M, Dubey SK. Pharmacological evaluation of Chrozophora tinctoria as wound healing potential in diabetic rat's model. Biomed Res Int 2016;2016;7475124.

14. Ganji SR, Mahboubeh R, Hamed K, Nanjundan PK, Deepak KK, Pradeep S, Devkar SS. Antinociceptive effect of Terminalia bellirica in diabetic peripheral neuropathy: a comparison with fluoxetin, imipramine and quercetin. Latin Am J Pharm 2012;31:520-25.

15. Mohanbabu AV, Tara S, Meena KK, Bairy KL, SmitaS. Evaluation of antiinflammatory and analgesic activities of alcoholic extract of Kaempferia galanga in rats. Indian $\mathrm{J}$ Physiol Pharmacol 2011;55:13-24.

16. Gray AM, Spencer PSJ, Sewell RDE. The involvement of the opioidergic system in the antinociceptive mechanism of action of antidepressant compounds. British J Pharmacol 1998;124:669-74.

17. Adams SS, Hebborn P, Nicholson JS. Some aspects of the pharmacology of ibufenac, a non-steroidal antiinflammatory agent. J Pharm Pharmacol 1968; 20:305-12. 
18. Khajuria DK, Patil ON, Karasik D, Razdan R. Development and evaluation of novel biodegradable chitosan based metformin intra-pocket dental film for the management of periodontitis and alveolar bone loss in a rat model. Arch Oral Biol 2018; 85:120-29.

19. Ramdas K, Suresh G, Janardhana N, Masilamani S. Antifungal activity of 1,3 disubstituted symmetrical and unsymmetrical thioureas. Pest Manag Sci 1998;52:145-51.

20. https://msu.edu/ freed/mstatc.htm.

21. Besra SE, Sharma RM. Gomes A. Anti-inflammatory effect of petroleum ether extract of leaves of Litchi chinensis Gaertn (Sapinadaceae) J Ethnopharmacol 1996; 54:1-6.

22. Magaji MG, Anuka JA, Abdu-Aguye I, Yaro AH, Hussaini IM. Behavioural effects of the methanolic root bark extract of Securinega virosa in rodents. Afr J Trad Complem Alter Med 2008;5:147-53.
23. Jigam AA, Razaq UTA, Egbuta MN. In vivo antimalarial and toxicological evaluation of Chrozophora senegalensis A. Juss (Euphorbiaceae) extracts. J Appl Pharm Sci 2011;1:90-94.

24. Lanhers MC, Fleurentin J, Dorfman P, Mortier F, Pelt JM. Analgesic, antipyretic and antiinflammatory properties of Euphorbia hirta. Planta Med 1991;57:225-31.

25. Igbinosa OO, Igbinosa EO, Aiyegoro OA. Antimicrobial activity and phytochemical screening of stem bark extracts from Jatropha curcas (Linn) Afr J Pharm Pharmacol 2009;3:58-62.

26. Nelofar A, suhail T, Ahmad S, Afza N, Khan ST. Evaluation of antibacterial activity of a locally available medicinal plant Euphorbia hirta. J Chem Soc Pak 2006;28:623-26.

27. Usman H, Musa YM, Ahmadu AA, Tijjani MA. Phytochemical and antimicrobial effects of Chrozophora Senegalensis. Afr J Trad Complem Alter Med 2007; 4:488-94. 